Marquette University

e-Publications@Marquette

Economics Faculty Research and Publications

Economics, Department of

$2-1-2015$

Implications of Globalization for the Outputinflation Relationship: An Assessment

Joseph P. Daniels

Marquette University, joseph.daniels@marquette.edu

Sandeep Mazumder

Wake Forest University

David D. VanHoose

Baylor University

Accepted version. Open Economies Review, Vol. 26, No. 1 (February 2015): 39-60. DOI. (C) 2015 Springer. Used with permission.

Shareable Link. Provided by the Springer Nature SharedIt content-sharing initiative. 


\title{
Implications of Globalization for the Output-inflation Relationship: An Assessment
}

\author{
Joseph P. Daniels \\ Department of Economics, Marquette University \\ Milwaukee, WI \\ Sandeep Mazumder \\ Department of Economics, Wake Forest University \\ Winston-Salem, NC \\ David D. VanHoose \\ Hankamer School of Business, Baylor University \\ Waco, TX
}

\begin{abstract}
:
During the past two decades, a growing body of research has explored the implications of increased trade and financial openness for the relationship between output and inflation. This paper reviews proposed theoretical channels through which the degree of openness might ultimately affect the output-inflation trade-off and surveys the empirical studies that have sought to determine the net effect of greater openness on this trade-off. In addition, the paper utilizes a single cross-country dataset to evaluate, taking into account recent developments in the literature, the likely sign and significance of this net effect. In particular, we find current data implies that there is a negative and significant relationship between openness and the sacrifice ratio, regardless of the transmission channel that is proposed.
\end{abstract}

Keywords: Openness, disinflation, sacrifice ratio. 
NOT THE PUBLISHED VERSION; this is the author's final, peer-reviewed manuscript. The published version may be accessed by following the link in the citation at the bottom of the page.

JEL Codes: F40, F41, F43

\section{Introduction}

Does increased globalization in the form of increased crossborder flows of trade in goods and services or of capital investment influence the nature of the trade-off between real output and inflation? If so, through what channels can increased globalization exert effects on the output-inflation relationship? What are the directions and relative magnitudes of these channels, and what are their net effects on the relationship? A number of economists have been wrestling with these questions during the past two decades. They have proposed several theories offering a number of reinforcing and conflicting channels through which increased openness to trade or capital flows conceivably could affect the output-inflation trade-off. In addition, economists have utilized a variety of measures of cross-border openness and a wide array of additional independent variables to assess the effects of greater openness on the sacrifice ratio and other possible measures of the relationship between output and inflation.

The purpose of this paper is to provide a full assessment of the fruits of these efforts to review both theoretical and empirical aspects of the interplay between globalization and the output-inflation tradeoff. One objective is to provide a complete overview of conceptual linkages that economists proposed might conceivably exist between greater international openness and the structural relationship between a nation's real output and inflation rate. Another goal is to review and evaluate the wide range of empirical findings to date. Toward this end, the paper employs updated cross- country data to compare and contrast key empirical approaches and model specifications utilized by previous authors. This multi-specification approach enables us to highlight why studies sometimes have yielded contrary results, how consideration of a particular set of independent variables alongside openness points toward general agreement on the net overall effect of globalization on the output-inflation trade-off, and why data limitations inherent in cross-country studies are likely to complicate efforts to sort out the effects of conflicting channels linking openness to this tradeoff.

The following section discusses the conflicting theoretical perspectives that have arisen over the years regarding the channels

Open Economies Review, Vol. 26, No. 1 (February 2015): pg. 39-60. DOI. This article is C Springer and permission has been granted for this version to appear in e-Publications@Marquette. Springer does not grant permission for this article to be further copied/distributed or hosted elsewhere without the express permission from Springer. 
through which globalization might be expected to impinge on the output-inflation relationship. Section 3 surveys the sometimes conflicting empirical conclusions that have emerged from efforts to evaluate the real-world extent to which these channels might exist. Section 4 employs updated cross-country data in an effort to assess sources of some conflicting results in past analyses, to point toward some signs of emerging agreement about the net effects of globalization on the trade-off, and to explain why assessing the roles of specific channels through which these effects arise may nonetheless prove difficult to evaluate. Section 5 concludes by contemplating possible directions for future research.

\section{Alternative Theoretical Perspectives}

There has long been an understanding that variations in the degree of international openness likely have macroeconomic implications across several dimensions. Viewed from the perspective of the output-inflation trade-off, a difficulty is that there are multiple channels and directions of effects that theoretically can be exerted by increased openness to trade or capital flows.

\subsection{How Greater Openness Might Make Aggregate Output Less Inflation-Sensitive}

Initial analyses of the relationship between globalization and the output-inflation relationship sought to rationalize an apparent inverse relationship between greater openness and the level of inflation [see Schwerhoff and Sy (2014) for a recent study focusing on transport cost openness]. Hence, the focus of early studies was placed on showing how increased openness might worsen the terms of the output-inflation trade- off faced by national monetary authorities, which in turn would reduce the incentives for national monetary authorities to generate higher inflation.

Thus, Romer's (1993) seminal study documenting in crosscountry data a negative relationship between inflation and the degree of trade openness suggests that terms-of-trade effects of output expansions alter the output-inflation relationship. In a more open economy, the resulting real depreciation would cause prices of foreign goods to rise proportionately faster compared with the increases of prices of domestic goods, resulting in higher CPI inflation.

Open Economies Review, Vol. 26, No. 1 (February 2015): pg. 39-60. DOI. This article is @ Springer and permission has been granted for this version to appear in e-Publications@Marquette. Springer does not grant permission for this article to be further copied/distributed or hosted elsewhere without the express permission from Springer. 
Furthermore, a real depreciation that boosted domestic firms' costs would generate a larger increase in domestic prices for any given output expansion. Another way to consider Romer's hypothesis is to envision two nations that conduct more trade effectively creating one larger economy. This essentially reduces openness and lowers the damage resulting from real depreciation caused by a surprise monetary expansion, which also thereby increases inflation. Thus openness and inflation should be negatively related.

Lane (1997) notes that Romer's terms-of-trade channel cannot explain a reduced sensitivity of output to inflation in nations with economies too small to exert effects on international relative prices. For such nations, Lane contends that greater trade openness reduces the potential output gains from unexpected inflation in non-tradedgoods sectors characterized by imperfect competition and sticky product prices.

Furthermore, Karras (1999) argues that greater indexation of nominal wages to unexpected inflation in response to increased trade openness also reduces the responsiveness of output to inflation. He demonstrates in the context of an aggregate demand-aggregate supply framework that the resulting steepening of the aggregate supply curve reduces the effects of monetary policy actions and hence diminishes the incentive for monetary authorities to inflate.

In a subsequent, widely cited discussion of the effects of globalization on inflation, Rogoff (2006, p. 269) also argues in favor of a steepening of the output- inflation relationship via increased openness. Rogoff suggests that the pro-competition effects of increased openness that "weaken the power of domestic monopolies and labor unions" contribute to greater flexibility of wages and prices. Increased wage and price flexibility, he concludes, "diminishes the output gains to be reaped from expansionary monetary policy for any given inflation impulse."

\subsection{How Greater Openness Might Make Aggregate Output More Inflation-Sensitive}

Bean's (2006, p. 2) discussion of Rogoff's (2006) analysis suggests that contrary to Rogoff's argument, "increased competition from labor-abundant economies means that businesses have less

Open Economies Review, Vol. 26, No. 1 (February 2015): pg. 39-60. DOI. This article is (C) Springer and permission has been granted for this version to appear in e-Publications@Marquette. Springer does not grant permission for this article to be further copied/distributed or hosted elsewhere without the express permission from Springer. 
scope to raise their prices in the face of strong demand." This more limited pricing reach, Bean argues, contributes to an outcome in which "domestic inflation becomes less sensitive to the domestic output gap," which results in a "flattening of the short-run Phillips curve" that "has indeed been observed in a number of industrialized countries and appears to be partly related to increased openness."

Bean cites empirical work (discussed below) by Daniels, Nourzad, and VanHoose (2005), which in turn is motivated by the theoretical analysis of Daniels and VanHoose (2006) suggesting that increased openness makes output more, not less, sensitive to inflation. Daniels and VanHoose demonstrate greater trade openness exposes imperfectly competitive firms to increased competition. The consequence is a reduction in firms' pricing power that effectively increases the responsiveness of firm- level output to changes in product prices. At an aggregate level, the implication is that a rise in openness to trade increases the range of variability of output for a given proportionate change in the price level-or, alternatively stated, a heightened sensitivity of aggregate output to the inflation rate. Daniels and VanHoose are able to reconcile simultaneously greater sensitivity of output to inflation and reduced mean inflation in response to increased globalization. Within their imperfectly competitive framework, greater openness makes firm-level output and, consequently, prices less sensitive to monetary expansions, which reduces inflationary policy incentives.

The Daniels and VanHoose framework and extensions indicate that other elements besides openness influence the output-inflation relationship. Daniels and VanHoose (2006) show that an increased responsiveness of domestic spending to the real terms of trade and an enlargement of the share of domestic labor markets with nominal rigidities also cause output to be more responsive to inflation, and Daniels and VanHoose (2009a) show that increased progressivity of income taxation can have a similar effect. In addition, Daniels, Nourzad, and VanHoose (2005) suggest that any factor, such as a greater degree of openness or an increase in central bank independence, that has the effect of pushing down mean inflation can also lead to greater nominal rigidities. Hence, any two studies that propose two alternative channels by which globalization affects the inflation-output relationship may yield equally significant findings,

Open Economies Review, Vol. 26, No. 1 (February 2015): pg. 39-60. DOI. This article is (C) Springer and permission has been granted for this version to appear in e-Publications@Marquette. Springer does not grant permission for this article to be further copied/distributed or hosted elsewhere without the express permission from Springer. 
even if these two approaches employ theoretically distinct ideas, as long as both factors lower mean inflation. For instance, Daniels, Nourzad, and VanHoose (2005) argue that central bank independence lowers average inflation, which contributes to increased nominal stickiness and hence makes output more inflation- sensitive. Consequently, there is less scope for increased openness simultaneously to yield consonant effects. Various authors have proposed potential roles for factors alongside globalization, including political regimes (Caporale and Caporale, 2008), costs of international trade and expenditure-switching effects (Cavelaars, 2009), exchangerate regimes (Bowdler, 2009), labor-market structures (Bowdler and Nunziata, 2010), and the extent of exchange-rate pass through (Daniels and VanHoose, 2013).

Pickering and Valle (2012) provide another view on the effect of increased globalization on the output-inflation relationship. They consider a setting in which domestic marginal production costs are influenced by expenses on inputs other than domestic labor, such as imported commodities and natural resources. Pickering and Valle argue that in contrast to domestic wages, prices of many such inputs are exogenous. Thus, as the degree of trade openness increases and firms utilize more imported inputs, there is a weakened link between output expansions and marginal production costs, resulting in a diminished effect of demand shocks on inflation. The result is a shallower Phillips curve, which corresponds to an increased responsiveness of output to inflation. Pickering and Valle suggest that the pure international-trade- openness effect on the output-inflation relationship could work in the opposite direction but that their proposed effect only works along this single foreign-input-price channel. Thus, they conclude that in theory the overall effect of increased globalization on the responsiveness of output to inflation could be either negative or positive.

Sbordone (2010) seeks to estimate the net competitive boost from openness on the slope of a new-Keynesian/sticky-price-based Phillips curve through a higher price elasticity of demand confronted by firms and a decrease in the elasticity of firms' desired markup. The former effect boosts the slope of the Phillips curve, but the latter effect reduces its slope. Based on a calibrated quantitative assessment using U.S. data from the 1960-2006 period, Sbordone concludes that the net

Open Economies Review, Vol. 26, No. 1 (February 2015): pg. 39-60. DOI. This article is (C) Springer and permission has been granted for this version to appear in e-Publications@Marquette. Springer does not grant permission for this article to be further copied/distributed or hosted elsewhere without the express permission from Springer. 
effect of increased openness for the United States is likely small-a result that echoes Neiss's (2001) conclusion that the effect of openness on inflation diminishes once markups are taken into account.

Of course, as discussed by Gruben and McLeod (2002, 2004), nations' economies also can become more globalized is via an increase in the degree of capital mobility. Razin and Yuen (2002), Loungani, Razin, and Yuen (2001), and Razin and Loungani (2005) have explored the effects of increased mobility of capital on the output-inflation relationship operating through aggregate-expenditure-smoothing effects. These effects contribute to increased price stickiness, which in turn implies greater variation in aggregate output for any given change in the inflation rate. These authors conclude, therefore, that there is a positive relationship between capital mobility and the observed responsiveness of output to the inflation rate. To explain how a greater extent of capital mobility could simultaneously contribute to greater sensitivity of output to inflation while at the same time reducing average inflation, Razin and Loungani argue that globalization has tended to boost policymakers' loss weight on inflation.

\section{Empirical Evidence}

During the years immediately following Romer's (1993) study, researchers directed most attention to evaluating the relationship between globalization and average inflation. This orientation changed in response to work by Temple (2002). For a set of 22 developed, high-income nations, Temple examines the relationship between import shares of GDP and average ratios of total output losses to changes in trend inflation rates during disinflationary periods, or sacrifice ratios, developed by Ball (1994). As additional control variables, Temple includes the initial, pre-disinflation inflation rate, the change in inflation, the length of the disinflation period, and Bruno and Sachs' (1985) measure of nominal contract duration. Statistical analysis based on both presumptions of linear and non-linear relationships between openness and the sacrifice ratio fail to offer strong evidence to support Romer's idea that a greater degree of openness is associated with a lower sacrifice ratio-that is, that greater openness makes a nation's aggregate output less sensitive to inflation. Although Temple obtains estimates of the coefficient linking the sacrifice ratio negatively with openness, these estimates were not statistically significant. To check for the robustness of this non-

Open Economies Review, Vol. 26, No. 1 (February 2015): pg. 39-60. DOI. This article is (C) Springer and permission has been granted for this version to appear in e-Publications@Marquette. Springer does not grant permission for this article to be further copied/distributed or hosted elsewhere without the express permission from Springer. 
significant relationship, Temple contemplates sacrifice ratios computed by Jordan (1997) using a slightly different methodology and "benefit ratios" that Jordan calculated to measure gains in output during periods of higher inflation. Temple also considers a broadened sample including 21 more middle- and lower-middle-income countries and evaluated the relationship between openness and estimates of outputinflation trade- offs for those nations provided by Ball, Mankiw, and Romer (1988). In all cases, Temple remains unable to reject the null hypothesis of no relationship between openness and measures of the relationship between output and inflation.

Daniels, Nourzad, and VanHoose (2005) re-examine Temple's results from the perspective that his omission of at least one crucial variable, central bank independence, could bias his empirical tests. They find that once the inflation-reducing effect of greater central bank independence is taken into account, there is evidence in Temple's cross-country data for developed, high-income nations that have both a higher degree of central bank independence and increased trade openness contribute to a higher sacrifice ratio. The estimated direct effects of both variables on the sacrifice ratio are both positive and economically and statistically significant. The estimated interaction effect of both variables is significantly negative, a result that is consistent with the argument that the scope of the positive effect of openness on the sacrifice ratio is reduced by a simultaneous positive influence of greater central bank independence.

Daniels and VanHoose (2009b) and Badinger (2009) contemplate the separate and combined effects of both an increased degree of trade openness and a greater extent of capital mobility. Daniels and VanHoose build on the analysis in Daniels, Norzad, and VanHoose (2005) by including capital-mobility measures separately from and alongside a trade-openness measure. They find that both measures of increased globalization are generally positively and significantly related to the sacrifice ratio, although strong negative interactions with central bank independence reduce the net magnitude of these positive relationships. Indeed, for some empirical specifications they consider, both measures of openness yield negative and/or statistically significant coefficient estimates. Daniels and VanHoose find high correlation between both openness measures that complicates assessing interactions between the two openness

Open Economies Review, Vol. 26, No. 1 (February 2015): pg. 39-60. DOI. This article is (C) Springer and permission has been granted for this version to appear in e-Publications@Marquette. Springer does not grant permission for this article to be further copied/distributed or hosted elsewhere without the express permission from Springer. 
measures; to the extent that effects of such interactions could be estimated, the effects were statistically insignificant. Badinger follows Ball, Mankiw, and Romer's (1988) methodology for measuring outputinflation trade-offs for 91 countries over the 1985-2004 interval. Utilizing these data and control variables that include measures of economy size and central bank independence, Badinger likewise finds evidence of generally positive and significant independent effects of both increased trade openness and a greater degree of capital mobility on the sensitivity of output to inflation.

Bowdler (2009) examines data from 19 nations that include sacrifice ratios applying to more recent periods than those examined by Temple and by Daniels, Nourzad, and VanHoose (2005) and data involving output-inflation trade-offs for a broadened sample of 41 countries. Bowdler also focuses attention on how the flexibility of exchange rates influences the relationship between openness and the sacrifice ratio. He provides results indicating that once one controls for the nature of the exchange-rate regime that is in place, greater evidence emerges supporting a negative relationship between openness and the sensitivity of output to inflation. Bowdler also finds evidence that once the nature of the exchange-rate regime is taken into account, the effect of greater central bank independence on the sacrifice ratio effectively disappears.

Pickering and Valle (2012) test their theory that an input-price channel operates alongside a trade-openness channel by including in sacrifice-ratio estimations both a traditional product-based openness measure of globalization and a measure of input openness given by the ratio of imports of commodity and energy inputs to GDP. Their estimates are derived from a sample of 36 nations, utilizing Bowdler's sacrifice-ratio estimates. Their results generally support Bowdler's conclusion that increased trade openness has a negative effect on the sacrifice ratio. In contrast, coefficient estimates for Pickering and Valle's input-based measure of globalization have an estimated positive and mostly statistically significant effect on the sacrifice ratio. These results, they suggest, offer support for their hypothesis that multifaceted aspects of increased globalization have mixed implications for the output-inflation relationship.

Daniels and VanHoose (2013) build on the Daniels and VanHoose (2006) theory by incorporating a role for incomplete pass

Open Economies Review, Vol. 26, No. 1 (February 2015): pg. 39-60. DOI. This article is (C) Springer and permission has been granted for this version to appear in e-Publications@Marquette. Springer does not grant permission for this article to be further copied/distributed or hosted elsewhere without the express permission from Springer. 
through of exchange-rate changes to import prices. Their analysis indicates that the effect of increased openness on the sensitivity of output to inflation operating through a direct shorter-term channel is positive but that an indirect, longer-term effect operating through the real-exchange-rate channel is negative. The interplay between openness and pass through across these two channels yields ambiguous predictions regarding the net effects of both openness and pass through on the output-inflation relationship. To try to evaluate the net effects, Daniels and VanHoose utilize Bowdler's methodology to compute sacrifice ratios for 20 nations for the 1975-2004 interval and employ Campa and Goldberg's (2005) estimates of the elasticity of exchange-rate pass through. They find evidence of a positive and statistically significant effect of an increased extent of pass through, which, as suggested by their theoretical model, is magnified by a greater degree of wage stickiness as proxied by union density. In contrast to their earlier studies, Daniels and VanHoose (2013) find evidence of a negative and statistically significant effect of openness on the sacrifice ratio-plus evidence that greater pass through reduces the absolute size of this negative effect. Consistent with Bowdler, Daniels and VanHoose (2013) find that the effects of central bank independence is diminished by taking into account exchange- ratebased influences on the interplay between openness and the outputinflation relationship. Overall, their results suggest that in the context of more recent data with more flexible exchange rates, the realexchange-rate channel through which openness affects the outputinflation relationship has become more important over time.

Clearly, the empirical evidence regarding the influence of trade openness on the output-inflation relationship has been mixed. One interpretation is that the inconclusive sign of the effect of increased trade openness on the sacrifice ratio and on output-inflation trade-off estimates reflects a complex array of interactions of openness and other variables. As noted above, proposed complicating factors include central bank independence, trade costs and product- versus inputmarket trade effects, exchange-rate regimes, differing degrees of exchange-rate pass through, and diverging labor-market structures. The confluence of all of these and other elements that may have independent or interacting effects of traditional trade- and capitalopenness measures could account for variations in directions of 
estimated effects of openness on the responsiveness of output to changes in the inflation rate.

An alternative interpretation is that the output-inflation relationship is largely immune to the state of globalization. Indeed, Ball's (2006) and Ihrig et al.'s (2010) analyses of data from 11 industrialized nations indicate that that the effects of increased openness are economically small and statistically insignificant. Qian (2012) contends, however, that both studies impose invalid zero restrictions and that the Ihrig et al. analysis suffers from serious omitted-variable problems. After correcting for these suggested problems, Qian employs Ihrig et al.'s essential methodology in country- specific time-series regressions and finds that increased trade openness is associated with shallower Phillips curves in Canada, Sweden, and the United States and a steeper Phillips curve in France. Nevertheless, Qian finds little evidence of strong effects of openness on the output-inflation relationship in the remaining countries. In a separate study that focuses on country-level time-series evidence of backward- and forward- looking Phillips curve specifications, Eijffinger and Qian (2010) likewise conclude that greater openness is associated with a Phillips-curve steepening in France, and they find a similar result for Australia and, in contrast to Qian (2012), the United States. Eijffinger and Qian find evidence favoring the view that globalization has made shallower the Phillips curve in the Netherlands.

\section{Reconciling the Empirical Evidence}

Given the varying components of the literature that have made different empirical arguments regarding the relationship between openness and the sacrifice ratio, we next turn our attention to whether it is possible to reconcile all of the competing stories. We do so by examining several key specifications using the same set of data updated to include the most recent available period.

\subsection{Data}

Our sacrifice ratio data are taken from Bowdler (2009), where the data set is extended to cover 1973 through 2004. Bowdler in turn computes the sacrifice ratio from the seminal work of Ball (1994), where the data are taken from the International Monetary Fund's International Financial Statistics.

Open Economies Review, Vol. 26, No. 1 (February 2015): pg. 39-60. DOI. This article is (C) Springer and permission has been granted for this version to appear in e-Publications@Marquette. Springer does not grant permission for this article to be further copied/distributed or hosted elsewhere without the express permission from Springer. 
Ball measures the sacrifice ratio by first identifying disinflation episodes. To do this, he examines the behavior of trend inflationmeasured as the centered eight- quarter moving average of actual quarterly inflation-where inflation peaks (troughs) are those periods in which trend in inflation in year $t$ is higher (lower) than in years $t-1$ and $t+1$. A disinflation episode is then defined as a period of time beginning with a peak and ending at a trough, where trend inflation declines by at least 1.5 percent. Thereafter Ball measures trend output by assuming output is at trend at the inflation peak, and returns to trend one year after the end of an episode. It is then assumed that trend output grows log-linearly between these two points, and the numerator of the sacrifice ratio is then the sum of the differences between this fitted line for trend output, and the log of actual output. The denominator of the sacrifice ratio is simply the amount of disinflation during an episode.

The resulting sacrifice ratio estimates represent the dependent variable of our analysis. Understanding the nature of this variable is very important as it drives, as well as limits, the empirical approach that one can take. Because the length, number, and start date of each disinflationary episode varies, the data are not structured as either a panel or unbalanced panel. Hence, a pooled ordinary-least-squares approach is used throughout the literature to estimate the determinants of the sacrifice ratio. Further, and as discussed next, many of the independent variables of interest are time invariant, and so fixed-effects models that rely on differencing data cannot be used. Rather, the approach is much more similar to an event study (see MacKinlay, 1997).

Our sample includes the sacrifice ratio (SAC) for 20 advanced economies. ${ }^{1}$ The episodic nature of the SAC measurement results in a limited number of observations, 69 in the models explored here, which will later make it important to consider the influence of extreme values. Table 1 displays descriptive statistics for the sacrifice ratio as well as for the independent variables we will examine in this paper. The sacrifice ratio ranges from -1.85 to 10.53 for all episodes in the sample, where the average length of each episode is approximately 4

\footnotetext{
${ }^{1}$ Australia, Austria, Belgium, Canada, Denmark, Finland, France, Germany, Ireland, Italy, Japan, Netherlands, New Zealand, Norway, Portugal, Spain, Sweden, Switzerland, UK, and US.
}

Open Economies Review, Vol. 26, No. 1 (February 2015): pg. 39-60. DOI. This article is (C) Springer and permission has been granted for this version to appear in e-Publications@Marquette. Springer does not grant permission for this article to be further copied/distributed or hosted elsewhere without the express permission from Springer. 
years. The average number of episodes per country in our sample is 3.45 disinflation episodes over the period 1973 to 2004. It should also be noted that the SAC measurement is skewed to the right and suffers from kurtosis, providing further evidence that there are the potential outliers in the data. We also estimated the within-country variance and between-country variance, finding that both aspects are relatively important in the SAC measurement. ${ }^{2}$

The independent variables we use in our analysis are taken from the literature described in Section 3. Some of the most often tested variables are the initial level of inflation at the outset of a disinflation episode, Inflation, the amount of disinflation over the course of an episode, $\boldsymbol{\Delta I n f l a t i o n , ~ a n d ~ t h e ~ l e n g t h ~ i n ~ y e a r s ~ o f ~ e a c h ~ e p i s o d e , ~ L e n g t h . ~}$ The literature commonly finds that the amount of disinflation produces a negative and significant coefficient in a sacrifice ratio regression, while Length is positive and significant. The latter is what gives rise to the notion of "cold-turkey" disinflation, where the faster the reduction in trend inflation, the less costly it is for an economy in terms of lost output. This has obviously important policy implications for central bankers who are contemplating a reduction in inflation.

To capture the degree of trade openness, Openness, we use Romer's (1993) measure, which is the ratio of imports to GDP, averaged over the entire sample period for each individual country. Some scholars have allowed the measure of openness to vary over time. Romer (see page 886, footnote 17 in particular), however, considers only the cross-sectional variation in openness, arguing that changes in openness are primarily due to policies and macroeconomic forces that also affect inflation. Hence, focusing solely on cross-section variance reduces the potential for endogeneity.

We also examine an index of central bank independence, CBI, following Daniels, Nourzad, and VanHoose (2005), where CBI data are taken from Franzese (2002). To capture the impact of exchange-rate pass through, Pass Through, on the sacrifice ratio we use Campa and Goldberg's (2005) estimates of long-run exchange-rate pass through as employed by Daniels and VanHoose (2013). We also account for the exchange rate regime, Exchange Rate Regime, as suggested in

\footnotetext{
2 The estimate of skewness is 2.016 and kurtosis is 10.423 . The within-cross-section standard deviation is 1.506 and the between-cross-section standard deviation is 1.162 .
}

Open Economies Review, Vol. 26, No. 1 (February 2015): pg. 39-60. DOI. This article is @ Springer and permission has been granted for this version to appear in e-Publications@Marquette. Springer does not grant permission for this article to be further copied/distributed or hosted elsewhere without the express permission from Springer. 
Bowdler (2009). This variable is the Ilzetzki, Reinhart, and Rogoff (2008) index for exchange rate regimes, where we take the average of the index of the years of each disinflation episode minus the sample mean over 1973-2004. Because Ball (1994) contends that greater wage flexibility has a downward influence upon sacrifice ratios, two measures of nominal wage rigidity are included. We first use the Bruno and Sachs (1985) measure of wage duration, Duration, and we subsequently use union density Union Density, where the data are taken from Visser (2009). Finally, we also consider the Pickering and Valle argument that inputs, Inputs, are important determinants of the sacrifice ratio, where this variable is the ratio of fuel and mining, iron and steel, machinery and transport products, chemicals, and textiles inputs relative to GDP, and input data are taken from the World Trade Organization's merchandise trade statistics.

Several of these key independent variables are time invariant: CBI, Duration, Openness, and Pass Through. In our empirical results that follow, these time-invariant variables allow us to estimate how key structural characteristics of an economy relate to the outputinflation tradeoff across countries. Other, time-variant measures allow us to consider the determinants of the output-inflation tradeoff across both countries and time.

\subsection{Results}

Next we turn our attention to regression analysis of the impact of Openness and other structural factors on the sacrifice ratio. Our objective here is to consider these factors in a single dataset and to progress in order with the literature discussed above. Table 2 contains our results for pooled ordinary least squares. Instead of assuming that error terms are independent between countries as well as within countries, we relax the latter assumption and report standard errors that allow for clustering at the country level.

Model (1) reports a base-model specification with only $\Delta$ Inflation, Length, Inflation, and Openness as explanatory variables (with error term $\varepsilon$ ):

$$
\begin{array}{r}
\text { SAC }=\text { Constant }+\beta_{1} \text { Openness }+\beta_{2} \text { Inflation }+ \\
\beta_{3} \text { Length }+\beta_{4} \text { Inflation }+\varepsilon
\end{array}
$$

Open Economies Review, Vol. 26, No. 1 (February 2015): pg. 39-60. DOI. This article is (C) Springer and permission has been granted for this version to appear in e-Publications@Marquette. Springer does not grant permission for this article to be further copied/distributed or hosted elsewhere without the express permission from Springer. 
This model provides evidence in favor of "cold-turkey" disinflation as the coefficient on Length is positive and statistically significant, indicating that a longer disinflation leads to greater output loss. Openness and $\boldsymbol{\Delta I n f l a t i o n}$ are negative and significant, although the latter only at the 10 percent level. We next scale the coefficients on Openness and Length to ascertain their economic significance. ${ }^{3}$ Based on the scaled coefficients, Openness tends to reduce the sacrifice ratio by -0.187 , while Length increases the sacrifice ratio by 0.679 . Thus, the magnitude of longer disinflations on the sacrifice ratio is greater than the degree of trade openness.

Model (2) in Table 2 parallels Temple (2002), who also controls for wage duration. The sample period used here differs slightly from Temple and we also treat the error terms differently by allowing for clustering of the errors. The inclusion of Duration causes the coefficient on Openness to fall from -0.024 to -0.015 , which also reduces its significance from the 1 percent level to 5 percent. Meanwhile, Length remains significant at the 1 percent level, but its coefficient also falls, from 0.636 to 0.587 . The coefficient on Duration itself is statistically indistinguishable from zero. In addition, the duration variable reduces the sample, excluding Ireland, Norway, Portugal, and Spain, possible leading to a sample-selection bias. Hence, we do not control for duration in any of the following models.

Model (3) follows Bowdler and Nunziata (2010) by including Union Density. Here we see that trade openness is highly negative and significant, while CBI is positive with a p-value of 0.078 . However, the results indicate that union density has no significant impact on the inflation-output tradeoff. Further, the sample size is slightly reduced in Model 3, as union density data are not available for four of our disinflation episodes (Denmark 1974-76, Ireland 1975-78, Norway 1981-85, and UK 1975-78). Based on the results of Models (2) and (3), we do not include wage duration or union density measures in the remaining models.

Model (4) follows Daniels, Nourzad, and VanHoose (2005) by conditioning for central bank independence and its interaction with

\footnotetext{
${ }^{3}$ This scaling amounts to multiplying the point estimate by the standard deviation of the regressor and dividing by the standard deviation of the dependent variable.
}

Open Economies Review, Vol. 26, No. 1 (February 2015): pg. 39-60. DOI. This article is @ Springer and permission has been granted for this version to appear in e-Publications@Marquette. Springer does not grant permission for this article to be further copied/distributed or hosted elsewhere without the express permission from Springer. 
trade openness. With these additional controls, the individual effect of Openness is no longer statistically significant. Though the interaction term with CBI is positive, it is not statistically significant. The total effect of Openness, measured at the mean value of CBI is negative and statistically significant (with a $\mathrm{p}$-value of less than 1 percent).

Model (5) is similar to Bowdler (2009) who includes controls for the exchange rate regime. We differ here in that Bowdler used the level of inflation and the square of inflation that prevailed at the start of a disinflationary episode whereas we include $\Delta$ Inflation, Length, and Inflation. In this model, Openness remains negative and significant while the interaction term of Openness and the exchangerate regime control is insignificant. The total effect of Openness, measured at the mean value of Exchange Rate, is negative and statistically significant. This finding is consistent with Bowdler, who argues that the sacrifice ratio is negatively related to openness and increased exchange rate flexibility strengthens this negative relationship.

Model (6) considers the role of inputs as in Pickering and Valle (2012). In this model, Inputs is positive and significant (with a pvalue of 0.097). However, Openness is no longer significant, while Length remains positive and significant (with a p-value of 0.001 ), and $\Delta$ Inflation is negative and significant (at the 10 percent significance level). It is important to note that the Inputs control reduces the sample significantly, which may well be driving the results for Inputs and Openness.

Models (7) and (8) consider the role of exchange-rate pass through as in Daniels and VanHoose (2013). The models differ in that Model (7) includes only the direct effect of Pass Through, while Model (8) includes the interaction of Pass Through and Openness. In both models, Openness is negative and significant while CBI and Length are positive. In Model (7), Pass Through is positive and significant (with a p-value of 0.094), a result which is explored further in Model (8). In this last model reported in Table 2, the interaction of Openness and Pass Through is significant and positive. The total effect of Openness, evaluated at the mean value of Pass Through, is statistically significant with a p-value of less than 1 percent. Hence, the results indicate that greater exchange rate pass through reduces the negative impact of openness on the sacrifice ratio.

Open Economies Review, Vol. 26, No. 1 (February 2015): pg. 39-60. DOI. This article is (C) Springer and permission has been granted for this version to appear in e-Publications@Marquette. Springer does not grant permission for this article to be further copied/distributed or hosted elsewhere without the express permission from Springer. 
NOT THE PUBLISHED VERSION; this is the author's final, peer-reviewed manuscript. The published version may be accessed by following the link in the citation at the bottom of the page.

\subsection{Outliers}

One potential problem of the results presented in Table 2 is the presence of outliers. As explained earlier, the episodic nature of the data leaves us with a relatively small number of observations on the dependent variable. The relatively small number of observations heightens the possibility of outliers influencing our results (and is suggested by both the skewness and kurtosis of the dependent variable). Hence, we employ the DFITS statistic to detect outliers. Instead of discarding observations and reducing our sample size, the DFITS statistic is then used to generate a weighted- influence control variable. This variable, not reported in the tables, reduces the weight afforded to observations with a high DFITS statistic ( 0.34 and above). ${ }^{4}$ Table 3 replicates the same specifications tested in Table 2, but with the influence of outliers reduced.

We see that controlling for outliers has a substantial impact on many of our results. Namely, we find that the amount of disinflation over the course of a disinflation episode is much more significant (i.e. there is strong evidence in favor of quicker disinflation, as in Ball, 1994), as is CBI and Pass Through. We also see that the economic relevance of several independent variables becomes more amplified when we control for potential outliers in the sample. For example in Model 2 of Table 3, Openness and $\Delta$ Inflation are negative and significant, while Length is positive and significant. The scaled coefficient for these three variables are $-0.144,-0.511$, and 0.695 respectively, compared to $-0.113,-0.418$, and 0.627 that we get in Model 2 of Table 2.

In Models (3), (7), and (8) in Table 3, we find that CBI is positive and significant as suggested by Daniels, Nourzad, and VanHoose (2005), while Openness is negative and significant in models involving each of these specifications as well, where Model (3) parallels the empirical model utilized by Bowdler and Nunziata (2012). We see the magnitude of trade openness is maximized in Model (8), where Openness produces a scaled coefficient of -0.446 . The Pass

\footnotetext{
${ }^{4}$ The control variable uses the value of 1 for all observations whose absolute value of the DFITS statistics is less than or equal to 0.34 . Those observations whose absolute value of the DFTIS statistic is greater than 0.34 are assigned a weight calculated as 0.34 /DFITS. See, for example, Maddala (1992).
}

Open Economies Review, Vol. 26, No. 1 (February 2015): pg. 39-60. DOI. This article is (c) Springer and permission has been granted for this version to appear in e-Publications@Marquette. Springer does not grant permission for this article to be further copied/distributed or hosted elsewhere without the express permission from Springer. 
Through variable also is positive and significant at the $5 \%$ level in Model (7), while the interaction between Pass Through and Openness in Model (8) continues to be significant (as argued by Daniels and VanHoose, 2013). We find the coefficient on $\mathbf{\Delta I n f l a t i o n}$ to also be highly relevant, even when controlling for CBI and Pass Through. In fact, almost every single variable tested in Table 3 yields a statistically significant coefficient, with the glaring exception of Inflation, which appears to have no bearing on the output costs of disinflation. In addition, we see that neither the Exchange Rate Regime nor Inputs appears to be important when we control for outliers [Models (5) and (6)], which implies that the Bowdler (2009) and Pickering and Valle (2012) arguments are weakened when controlling for outliers.

Finally, in Table 4 we control for outliers in a slightly different way: by using least absolute deviations (LAD) estimation with bootstrapped standard errors. LAD regression analysis differs from OLS in the sense that we minimize the sum of the absolute deviations of the fitted values from the observed values, as opposed to the sum of squared deviations as is done with least squares. An LAD regression estimates parameters of the conditional median (equivalent to a quantile regression at the 0.5 quantile) of the dependent variable given the independent variables. The main advantage of LAD estimation versus OLS is that, because it is based on the conditional median rather than the conditional mean, it is less sensitive to outliers than least squares (see for example Wooldridge, 2013, page 334). The trade-off or downside to this approach is that the LAD does not consistently estimate the parameters of the conditional mean. Hence, we must exercise caution when comparing parameter estimates across the two models as differences in the parameters of the OLS estimator and the LAD estimator may be due to reasons other than just outliers (see Wooldridge, 2010, p.451). In Model 1, the base model, the observation for Finland, 1989-1996, is assigned a weight of zero by the LAD. This observation is the largest SAC measurement in the sample at 10.529 .

The results in Table 4 indicate that our findings from Table 3 are tempered when we consider a robust estimation technique. For instance, when we implement pooled OLS with a weighted-influence control for outliers (Table 3), we find Openness to be negative and significant in 6 out of the 8 specifications tested. However with LAD

Open Economies Review, Vol. 26, No. 1 (February 2015): pg. 39-60. DOI. This article is (C) Springer and permission has been granted for this version to appear in e-Publications@Marquette. Springer does not grant permission for this article to be further copied/distributed or hosted elsewhere without the express permission from Springer. 
estimation (Table 4), Openness achieves a negative and significant coefficient only 4 times, producing significant coefficients for

Openness that range from -0.211 in Model (1) of Table 4 to -0.229 in Model (7), where we scale these coefficients. While Openness is not as statistically significant as before, it appears to still be an empirically important determinant of the sacrifice ratio. The most robust determinant of the sacrifice ratio remains to be Length, which is positive and significant in every single specification in Table 4. However, apart from Openness and Length, no other variable-be it CBI, Pass Through, or anything else-ever achieves statistical significance in our LAD results.

\subsection{Discussion}

The results obtained in this section indicate that trade openness is an empirically important determinant of the sacrifice ratio. Moreover, our evidence seems to support the Romer (1993) notion that openness and inflation (and hence openness and the sacrifice ratio) are negatively related to each other. However the findings in this paper suggest that several other factors may play an important role as well, including central bank independence, exchange-rate pass through, and the interactions among many independent variables. In addition, our estimation methodology reveals that the results that one obtains are sensitive to the choice of standard errors and to the treatment of outliers.

Our study reveals, therefore, that three main roadblocks appear when trying to investigate the relationship between openness and the sacrifice ratio-limitations that are apparent across the literature. First, when using annual data for 1973-2004 we obtain 69 disinflation episodes, which is a rather small sample size. This is quite typical for cross-country macroeconomic research, particularly for an area which focuses on an episodic measure of the sacrifice ratio, which is precisely the nature of Ball's sacrifice ratio measure. Aside from usual small sample problems that arise, having only 69 disinflation episodes inhibits our ability to test several competing theories simultaneously, where each of these theories-each of which posits a specific transmission channel from trade openness to inflation-because we would be left with a severely reduced number of degrees of freedom.

Open Economies Review, Vol. 26, No. 1 (February 2015): pg. 39-60. DOI. This article is (C) Springer and permission has been granted for this version to appear in e-Publications@Marquette. Springer does not grant permission for this article to be further copied/distributed or hosted elsewhere without the express permission from Springer. 
NOT THE PUBLISHED VERSION; this is the author's final, peer-reviewed manuscript. The published version may be accessed by following the link in the citation at the bottom of the page.

Second, outliers appear to strongly influence the results we obtain. This can be seen in comparing Tables 2-4, where we change our treatment of the outlying observations. For instance, using the weighted-influence control for outliers produced strong results in terms of statistical significance, whereas LAD estimation does the opposite and yields little to no statistical significance.

Third, and relatedly, there are potential omitted-variable issues when comparing the results from different specifications, as well as the possibility of relationships among independent variables that are ignored by the researcher. For example, the degree of trade openness is quite likely to be influenced by the choice of a nation's exchange rate regime.

\section{Conclusion and Directions for Future Research}

In this paper, we have tried to reconcile several competing theories with regards to the relationship between the degree of openness and the sacrifice ratio. Some theories highlight certain channels while simultaneously downplaying alternative channels. In an ideal world we could explore all of these hypotheses at the same time, but the three problems enumerated above prevent us from doing so. Based on our broad overview of the literature, we conclude that a relationship between trade openness and the output costs of disinflation undoubtedly exists.

Accurately assessing the empirical relationship between the two variables in light of the paucity of cross-country data available to researchers is definitely a non- trivial task, however. Theoretical considerations suggest that a number of potentially offsetting and interacting channels ultimately determine the observed net relationship between measures of openness and the sacrifice ratio.

Simultaneously analyzing the relative degrees of importance of all of these competing channels using sacrifice-ratio regressions is infeasible given the limited cross-country data available to researchers. This constraint has forced economists working on this topic to consider empirical models limited to relatively small sets of variables of greatest interest given the particular areas of focus in their own research projects. To some extent, this fact surely helps to account for one source of variation in estimated directions of the net estimated effect of the degree of openness on the sacrifice ratio.

Open Economies Review, Vol. 26, No. 1 (February 2015): pg. 39-60. DOI. This article is (C) Springer and permission has been granted for this version to appear in e-Publications@Marquette. Springer does not grant permission for this article to be further copied/distributed or hosted elsewhere without the express permission from Springer. 
Early work utilizing data through the end of the 1990s suggested at best either a nonexistent or weak negative relationship between the extent of openness and the sacrifice ratio. Later research indicated a positive relationship once the degree of central bank independence was taken into account. Updating the data to include the early 2000s - while simultaneously taking into account other variables such as the extent of exchange rate pass through - leads to a more nearly uniform finding across studies, including ours in this paper, of a negative relationship, on net. Thus, based on analysis of the full set of cross-country data available and taking into account various likely elements influencing the openness-sacrifice ratio relationship, our conclusion is that the weight of the evidence favors a negative relationship.

It is important to emphasize that this conclusion applies to analysis of the currently available cross-country data. As discussed by Daniels and VanHoose (2005, pp. 518-529) and emphasized by Eijffinger and Qian (2010) and Qian (2012), there is considerable scope for the relationship between the degree of openness and the output- inflation trade-off to vary across countries and potentially across time as well. This fact suggests that the work of Eijffinger and Qian points to one possible approach that researchers might pursue in future work on this topic, which is to study time-series data for individual nations. Unfortunately, for many countries there is an insufficient amount of data to permit conducting statistically robust sacrifice-ratio-based analyses for individual nations. Consequently, researchers contemplating moving the direction of national-level timeseries analysis likely will find themselves wrestling as well with the numerous controversies regarding appropriate approaches to Phillipscurve estimation.

In this paper, we have emphasized the cross-country approach utilized by most economists to date. In our view, the range of variables contemplated by past studies and considered in this paper encompass the set of elements that theories to date have identified as most likely to condition the relationship between standard measures of openness and the sacrifice ratio. Some enterprising researchers, however, may be able to identify previously unexplored economic variables that theoretically might also impinge on this relationship and to undertake econometric analyses of the empirical role of such

Open Economies Review, Vol. 26, No. 1 (February 2015): pg. 39-60. DOI. This article is (C) Springer and permission has been granted for this version to appear in e-Publications@Marquette. Springer does not grant permission for this article to be further copied/distributed or hosted elsewhere without the express permission from Springer. 
NOT THE PUBLISHED VERSION; this is the author's final, peer-reviewed manuscript. The published version may be accessed by following the link in the citation at the bottom of the page.

variables. Any researchers who choose to continue down this established path, however, almost certainly will encounter data limitations that we have highlighted.

\section{REFERENCES}

Badinger, Harald, 2009, Globalization, the output-inflation trade-off, and inflation, European Economic Review 53, 888-907.

Ball, Laurence, 2006, Has globalization changed inflation? NBER Working Paper 12687, November.

Ball, Laurence, 1994, What determines the sacrifice ratio?, in Monetary Policy, edited by N.G. Mankiw, pp. 155-182, Chicago, IL: University of Chicago Press.

Ball, Laurence, N. Gregory Mankiw, and David Romer, 1988, The new Keynesian economics and the output-inflation trade-off, Brookings Papers on Economic Activity, 1-65.

Barro, Robert, and David Gordon, 1983, A positive theory of monetary policy in a natural rate model, Journal of Political Economy 91, 589-610.

Bean, Charles, 2006, Comments on Ken Rogoff: "Impact of globalization on monetary policy," Federal Reserve Bank of Kansas City Jackson Hole Conference, August (http://www.kc.frb.org/publicat/sympos/2006/PDF/Bean.paper.0822.p df).

Bowdler, Christopher, 2009, Openness, exchange rate regimes, and the Phillips curve, Journal of International Money and Finance 28, 148160.

Bowdler, Christopher, and Luca Nunziata, 2010, Labor Market Structures and the Sacrifice Ratio, Journal of Macroeconomics 32, 816-826.

Bruno, Michael, and Jeffrey Sachs, 1985, Economics of worldwide stagflation, Harvard University Press, Cambridge, MA.

Campa, José Manuel, and Linda S. Goldberg, 2005, Exchange rate passthrough into import prices, The Review of Economics and Statistics 87, 679-690.

Caporale, Barbara, and Tony Caporale, 2008, Political regimes and the cost of disinflation, Journal of Money, Credit and Banking 40, 1541-1554.

Cavelaars, Paul, 2009, Does globalization discipline monetary policymakers? Journal of International Money and Finance 28, 392-405.

Open Economies Review, Vol. 26, No. 1 (February 2015): pg. 39-60. DOI. This article is (C) Springer and permission has been granted for this version to appear in e-Publications@Marquette. Springer does not grant permission for this article to be further copied/distributed or hosted elsewhere without the express permission from Springer. 
NOT THE PUBLISHED VERSION; this is the author's final, peer-reviewed manuscript. The published version may be accessed by following the link in the citation at the bottom of the page.

Daniels, Joseph, and David VanHoose, 2013, Exchange-rate pass through, openness, and the sacrifice ratio, Journal of International Money and Finance, 36 (September 2013), 131-150.

Daniels, Joseph, and David VanHoose, 2009a, Openness, income-tax progressivity, and inflation, Journal of Macroeconomics 31, 485-491.

Daniels, Joseph, and David VanHoose, 2009b, Trade openness, capital mobility, and the sacrifice ratio, Open Economies Review 20, 473-487.

Daniels, Joseph, Farrokh Nourzad, and David D. VanHoose, 2006, Openness, Centralized Wage Bargaining, and Inflation, European Journal of Political Economy 22, 969-988.

Daniels, Joseph, and David VanHoose, 2006, Openness, the sacrifice ratio, and inflation: Is there a puzzle? Journal of International Money and Finance 25, 1336-1347.

Daniels, Joseph, and David VanHoose, 2005, International Monetary and Financial Economics, 3rd Edition, Thomson-Southwestern.

Daniels, Joseph, Farrokh Nourzad, and David VanHoose, 2005, Openness, central bank independence, and the sacrifice ratio, Journal of Money, Credit, and Banking 37, 371-379.

Eijffinger, Sylvester C.W., and Zongxin Qian, 2010, Globalization and the Output- Inflation Trade-Off, European Banking Discussion Paper No. 2010-04, Tilburg University, March.

Franzese, Robert J. Jr., 2002, Macroeconomic Policies of Developed Democracies, Cambridge Studies in Comparative Politics, Cambridge: Cambridge University Press.

Gruben, William, and Darryl McLeod, 2004, Capital market liberalization, disinflation, and commitment, Manuscript, Federal Reserve Bank of Dallas and Fordham University.

Gruben, William, and Darryl McLeod, 2002, Capital account liberalization and inflation, Economics Letters 77, 221-225.

Ihrig, Jane, Steven Kamin, Deborah Lindner, and Jaime Marquez, 2010, Some simple tests of the globalization and inflation hypothesis, International Finance 13, 343- 375.

Ilzetzki, Ethan, Carmen Reinhart, and Kenneth Rogoff, 2008, Exchange rate arrangements entering the 21st century: which anchor will hold?, (unpublished; University of Maryland and Harvard University).

Open Economies Review, Vol. 26, No. 1 (February 2015): pg. 39-60. DOI. This article is (C) Springer and permission has been granted for this version to appear in e-Publications@Marquette. Springer does not grant permission for this article to be further copied/distributed or hosted elsewhere without the express permission from Springer. 
NOT THE PUBLISHED VERSION; this is the author's final, peer-reviewed manuscript. The published version may be accessed by following the link in the citation at the bottom of the page.

Jordan, Thomas, 1997, Disinflation Costs, Accelerating Inflation Gains, and Central Bank Independence, Weltwirtschaftliches Archiv 133, 1-21.

Karras, George, 1999, Openness and the effects of monetary policy, Journal of International Money and Finance 18, 13-26.

Lane, Philip, 1997, Inflation in open economies, Journal of International Economics 42, 327- 347.

Loungani, Prakas, Assaf Razin, and Chi-Wa Yuen, 2001, Capital mobility and the output-inflation trade-off. Journal of Development Economics 64, 255-274.

MacKinlay, Craig, 1997, Event Studies in Economics and Finance, Journal of Economic Literature XXXV, 13-39.

Maddala, G.S., 1992, Introduction to Econometrics, Second Edition, Englewood Cliffs, NY: Prentice Hall Publishing.

Neiss, Katharine, 2001, The markup and inflation: Evidence in OECD countries, Canadian Journal of Economics 34, 570-587.

Nickell, Stephen, Luca Nunziata, and Wolfgang Ochel, 2005, Unemployment in the OECD since the 1960s: What Do we Know? Economic Journal 115, 1-27.

Pickering, Andrew, and Héctor Valle, 2012, Openness, imported commodities, and the sacrifice ratio, BE Journal of Macroeconomics (Topics) 12, Article 8

Qian, Zongxin, 2012, Essays on Globalization, Monetary Policy and Financial Crisis, Dissertation, University of Tilburg.

Razin, Assaf, and Prakash Loungani, 2005, Globalization and equilibrium output- inflation trade-offs. NBER Working Paper 11641, September.

Razin, Assaf, and Chi-Wa Yuen, 2002, The 'new Keynesian' Phillips curve: Closed economy versus open economy, Economics Letters 75, 1-9.

Rogoff, Kenneth, 2006, Impact of Globalization on Monetary Policy, Federal Reserve Bank of Kansas City Jackson Hole Conference Published Proceedings, August, pp. 265-305

Romer, David, 1993, Openness and inflation: Theory and evidence, Quarterly Journal of Economics 108, 869-903.

Sbordone, Argia, 2010, Globalization and inflation dynamics: The impact of increased competition, In International Dimensions of Monetary Policy,

Open Economies Review, Vol. 26, No. 1 (February 2015): pg. 39-60. DOI. This article is (C) Springer and permission has been granted for this version to appear in e-Publications@Marquette. Springer does not grant permission for this article to be further copied/distributed or hosted elsewhere without the express permission from Springer. 
NOT THE PUBLISHED VERSION; this is the author's final, peer-reviewed manuscript. The published version may be accessed by following the link in the citation at the bottom of the page.

ed. Jordi Gali and Mark Gertler, Chicago: University of Chicago Press, pp. 547-579.

Schwerhoff, Gregor, and Mouhamadou Sy, 2014, "The Non-Monetary Side of the Global Disinflation," Open Economies Review 25, 337-371.

Temple, Jonathan, 2002, Openness, inflation, and the Phillips curve: a puzzle. Journal of Money, Credit, and Banking 34, 450-468.

Visser, Jelle, 2009, The ICTWSS Database: Database on institutional characteristics of trade unions, wage setting, state intervention and social pacts in 34 countries between 1960 and 2007. University of Amsterdam.

Wooldridge, Jeffrey M., 2013, Introductory Econometrics: A Modern Approach, 5th Edition, Mason, Ohio: South-Western Cengage Learning.

Wooldridge, Jeffery M., 2010, Econometric Analysis of Cross Section and Panel Data, Second Edition, Cambridge, MA: The MIT Press.

Table 1. Descriptive Statistics

\begin{tabular}{lrrrrrr}
\hline & Mean & Median & Maximum & Minimum & Std. Dev. & Observations \\
\hline Sacrifice Ratio & 1.4171 & 1.3030 & 10.5290 & -1.8510 & 1.8362 & 69 \\
Openness & 31.3078 & 29.2800 & 65.6100 & 10.0800 & 14.0876 & 69 \\
CBI & 0.4525 & 0.4193 & 0.9314 & 0.1505 & 0.1961 & 69 \\
Exchange Rate Regime & 0.0139 & 0.0313 & 1.0938 & -1.6875 & 0.5413 & 69 \\
Inflation & 6.1576 & 5.3088 & 17.9950 & 1.5287 & 4.2318 & 69 \\
Inflation & 9.9860 & 8.8612 & 27.5863 & 1.2708 & 5.9641 & 69 \\
Length & 4.4638 & 4.0000 & 11.0000 & 1.0000 & 1.9597 & 69 \\
Duration & 1.3818 & 2.0000 & 2.0000 & 0.0000 & 0.7815 & 55 \\
Inputs & 0.0692 & 0.0501 & 0.2088 & 0.0071 & 0.0522 & 47 \\
Union Density & 43.6323 & 43.9000 & 79.4200 & 9.9900 & 18.7196 & 65 \\
Pass Through & 0.6170 & 0.6700 & 1.1300 & 0.0600 & 0.3143 & 69 \\
\hline
\end{tabular}

Open Economies Review, Vol. 26, No. 1 (February 2015): pg. 39-60. DOI. This article is (c) Springer and permission has been granted for this version to appear in e-Publications@Marquette. Springer does not grant permission for this article to be further copied/distributed or hosted elsewhere without the express permission from Springer. 
NOT THE PUBLISHED VERSION; this is the author's final, peer-reviewed manuscript. The published version may be accessed by following the link in the citation at the bottom of the page.

Table 2: Sacrifice Ratio Estimates Based on Pooled OLS Robust Standard Errors Clustered at the Country Level in Parentheses

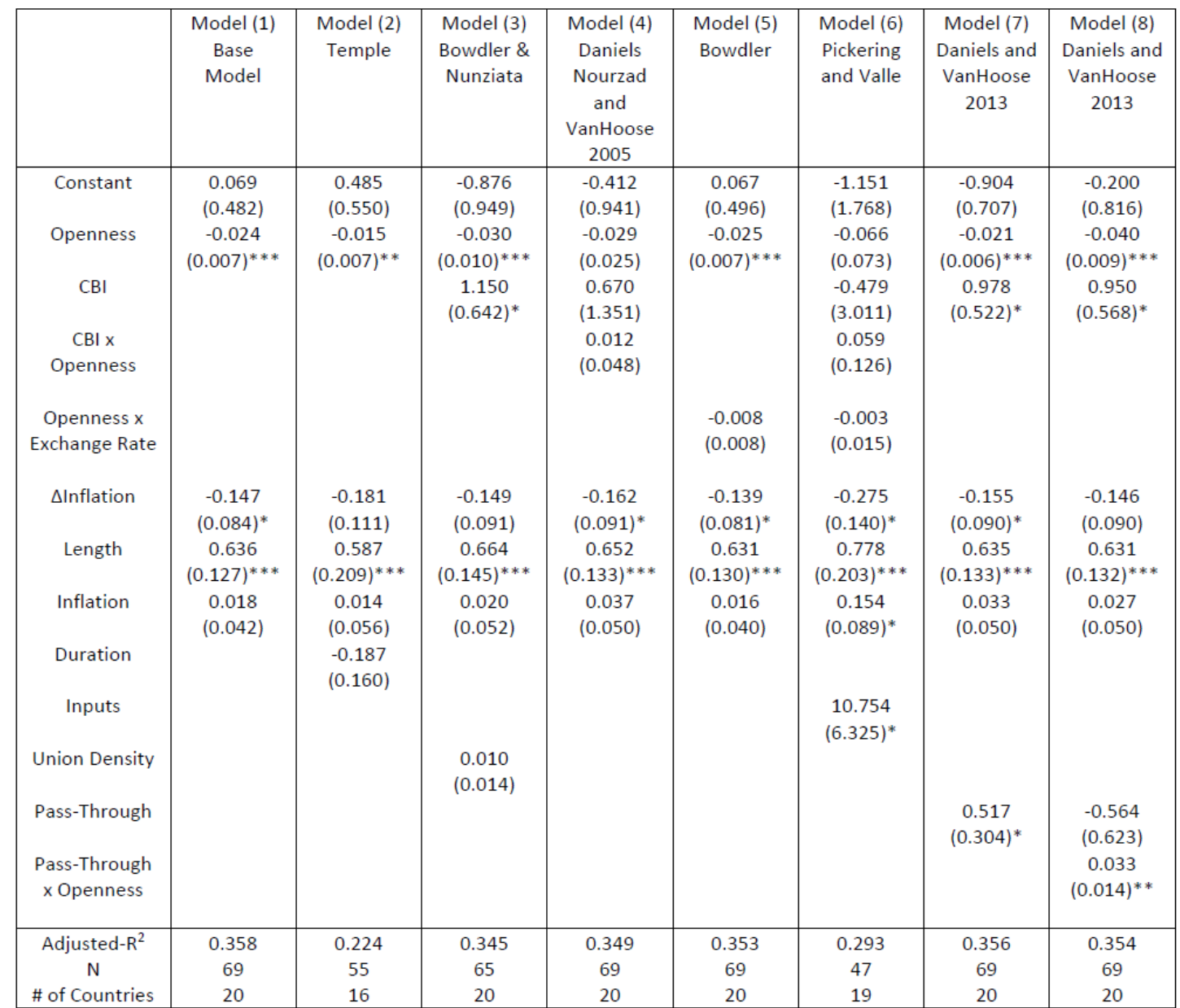

$* * *, * *$, and $*$ denote 1,5 , and $10 \%$ levels of significance respectively.

Open Economies Review, Vol. 26, No. 1 (February 2015): pg. 39-60. DOI. This article is (C) Springer and permission has been granted for this version to appear in e-Publications@Marquette. Springer does not grant permission for this article to be further copied/distributed or hosted elsewhere without the express permission from Springer. 
NOT THE PUBLISHED VERSION; this is the author's final, peer-reviewed manuscript. The published version may be accessed by following the link in the citation at the bottom of the page.

Table 3: Sacrifice Ratio Estimates Based on Pooled OLS with Weighted-Influence Control for Outliers Robust Standard Errors Clustered at the Country Level in Parentheses

\begin{tabular}{|c|c|c|c|c|c|c|c|c|}
\hline & $\begin{array}{c}\text { Model (1) } \\
\text { Base } \\
\text { Model }\end{array}$ & $\begin{array}{l}\text { Model (2) } \\
\text { Temple }\end{array}$ & $\begin{array}{c}\text { Model (3) } \\
\text { Bowdler \& } \\
\text { Nunziata }\end{array}$ & $\begin{array}{l}\text { Model (4) } \\
\text { Daniels } \\
\text { Nourzad } \\
\text { and } \\
\text { VanHoose } \\
2005\end{array}$ & $\begin{array}{c}\text { Model (5) } \\
\text { Bowdler }\end{array}$ & $\begin{array}{l}\text { Model (6) } \\
\text { Pickering } \\
\text { and Valle }\end{array}$ & $\begin{array}{c}\text { Model (7) } \\
\text { Daniels and } \\
\text { VanHoose } \\
2013\end{array}$ & $\begin{array}{c}\text { Model (8) } \\
\text { Daniels and } \\
\text { VanHoose } \\
2013\end{array}$ \\
\hline Constant & $\begin{array}{c}6.549 \\
(1.677)^{* * *}\end{array}$ & $\begin{array}{c}7.278 \\
(1.988)^{* * *}\end{array}$ & $\begin{array}{c}5.765 \\
(1.465)^{* * *}\end{array}$ & $\begin{array}{c}5.093 \\
(1.712)^{* * *}\end{array}$ & $\begin{array}{c}6.521 \\
(1.702)^{* * *}\end{array}$ & $\begin{array}{c}7.577 \\
(2.305)^{* * *}\end{array}$ & $\begin{array}{c}5.407 \\
(1.458)^{* * *}\end{array}$ & $\begin{array}{c}6.742 \\
(1.716)^{* * *}\end{array}$ \\
\hline Openness & -0.032 & $\begin{array}{c}-0.019 \\
(0.005) * * *\end{array}$ & $\begin{array}{c}-0.031 \\
(0.011)^{* * *}\end{array}$ & $\begin{array}{l}-0.005 \\
(0.034)\end{array}$ & $\begin{array}{c}-0.032 \\
(0.012)^{* *}\end{array}$ & $\begin{array}{r}-0.009 \\
(0.073)\end{array}$ & $\begin{array}{c}-0.027 \\
(0.009)^{* * *}\end{array}$ & -0.058 \\
\hline $\mathrm{CBI}$ & & & $\begin{array}{c}1.718 \\
(0.543)^{* * *}\end{array}$ & $\begin{array}{c}(0.034) \\
3.071 \\
(2.023)\end{array}$ & (0.012) & $\begin{array}{c}2.852 \\
(3.123)\end{array}$ & $\begin{array}{c}1.429 \\
(0.510)^{* * *}\end{array}$ & $\begin{array}{c}1.397 \\
(0.536)^{* *}\end{array}$ \\
\hline $\begin{array}{c}\text { CBIx } \\
\text { Openness }\end{array}$ & & & & $\begin{array}{l}-0.056 \\
(0.066)\end{array}$ & & $\begin{array}{l}-0.067 \\
(0.123)\end{array}$ & & \\
\hline $\begin{array}{c}\text { Openness } x \\
\text { Exchange Rate }\end{array}$ & & & & & $\begin{array}{l}-0.004 \\
(0.007)\end{array}$ & $\begin{array}{l}-0.022 \\
(0.013)\end{array}$ & & \\
\hline$\Delta$ Inflation & $\begin{array}{c}-0.202 \\
(0.067)^{* * *}\end{array}$ & $\begin{array}{c}-0.222 \\
(0.103)^{* *}\end{array}$ & $\begin{array}{c}-0.224 \\
(0.068)^{* * *}\end{array}$ & $\begin{array}{c}-0.218 \\
(0.067)^{* * * *}\end{array}$ & $\begin{array}{c}-0.197 \\
(0.068)^{* * *}\end{array}$ & $\begin{array}{l}-0.166 \\
(0.107)\end{array}$ & $\begin{array}{c}-0.215 \\
(0.062)^{* * *}\end{array}$ & $\begin{array}{c}-0.203 \\
(0.071)^{* * *}\end{array}$ \\
\hline Length & $\begin{array}{c}0.668 \\
(0.102)^{* * *}\end{array}$ & $\begin{array}{c}0.651 \\
(0.170)^{* * *}\end{array}$ & $\begin{array}{c}0.701 \\
(0.105)^{* * *}\end{array}$ & $\begin{array}{c}0.691 \\
(0.099)^{* * *}\end{array}$ & $\begin{array}{c}0.665 \\
(0.102)^{* * *}\end{array}$ & $\begin{array}{c}0.586 \\
(0.150)^{* * *}\end{array}$ & $\begin{array}{c}0.665 \\
(0.095)^{* * *}\end{array}$ & $\begin{array}{c}0.660 \\
(0.104)^{* * *}\end{array}$ \\
\hline $\begin{array}{l}\text { Inflation } \\
\text { Duration }\end{array}$ & $\begin{array}{c}0.014 \\
(0.034)\end{array}$ & $\begin{array}{c}0.019 \\
(0.056) \\
-0.016 \\
(0.170)\end{array}$ & $\begin{array}{c}0.039 \\
(0.037)\end{array}$ & $\begin{array}{c}0.036 \\
(0.034)\end{array}$ & $\begin{array}{c}0.013 \\
(0.035)\end{array}$ & $\begin{array}{c}0.017 \\
(0.074)\end{array}$ & $\begin{array}{c}0.036 \\
(0.034)\end{array}$ & $\begin{array}{c}0.027 \\
(0.037)\end{array}$ \\
\hline $\begin{array}{l}\text { Inputs } \\
\text { Union Density }\end{array}$ & & & $\begin{array}{c}0.006 \\
(0.006)\end{array}$ & & & $\begin{array}{c}2.857 \\
(5.157)\end{array}$ & & \\
\hline $\begin{array}{l}\text { Pass-Through } \\
\text { Pass-Through } \\
\text { x Openness }\end{array}$ & & & & & & & $\begin{array}{c}0.866 \\
(0.396)^{* *}\end{array}$ & $\begin{array}{c}-0.909 \\
(0.550) \\
0.054 \\
(0.016)^{* * *}\end{array}$ \\
\hline Adjusted- $R^{2}$ & 0.628 & 0.584 & 0.654 & 0.642 & 0.623 & 0.689 & 0.662 & 0.679 \\
\hline $\mathrm{N}$ & 69 & 55 & 65 & 69 & 69 & 47 & 69 & 69 \\
\hline \# of Countries & 20 & 16 & 20 & 20 & 20 & 19 & 20 & 20 \\
\hline
\end{tabular}

$* * *, * *$, and $*$ denote 1,5 , and $10 \%$ levels of significance respectively

Open Economies Review, Vol. 26, No. 1 (February 2015): pg. 39-60. DOI. This article is C Springer and permission has been granted for this version to appear in e-Publications@Marquette. Springer does not grant permission for this article to be further copied/distributed or hosted elsewhere without the express permission from Springer. 
NOT THE PUBLISHED VERSION; this is the author's final, peer-reviewed manuscript. The published version may be accessed by following the link in the citation at the bottom of the page.

Table 4: Sacrifice Ratio Estimates Based on LAD Estimation Bootstrapped Standard Errors in Parentheses

\begin{tabular}{|c|c|c|c|c|c|c|c|c|}
\hline & $\begin{array}{l}\text { Model (1) } \\
\text { Base } \\
\text { Model }\end{array}$ & $\begin{array}{l}\text { Model (2) } \\
\text { Temple }\end{array}$ & $\begin{array}{c}\text { Model (3) } \\
\text { Bowdler \& } \\
\text { Nunziata }\end{array}$ & $\begin{array}{l}\text { Model (4) } \\
\text { Daniels } \\
\text { Nourzad } \\
\text { and } \\
\text { VanHoose } \\
2005\end{array}$ & $\begin{array}{l}\text { Model (5) } \\
\text { Bowdler }\end{array}$ & $\begin{array}{l}\text { Model (6) } \\
\text { Pickering } \\
\text { and Valle }\end{array}$ & $\begin{array}{c}\text { Model (7) } \\
\text { Daniels and } \\
\text { VanHoose } \\
2013\end{array}$ & $\begin{array}{c}\text { Model (8) } \\
\text { Daniels and } \\
\text { VanHoose } \\
2013\end{array}$ \\
\hline Constant & $\begin{array}{c}0.826 \\
(0.936)\end{array}$ & $\begin{array}{c}1.370 \\
(1.003)\end{array}$ & $\begin{array}{c}0.019 \\
(1.551)\end{array}$ & $\begin{array}{c}-0.553 \\
(2.102)\end{array}$ & $\begin{array}{c}0.830 \\
(0.944)\end{array}$ & $\begin{array}{c}-1.521 \\
(3.001)\end{array}$ & $\begin{array}{c}0.269 \\
(1.281)\end{array}$ & $\begin{array}{c}0.206 \\
(1.826)\end{array}$ \\
\hline Openness & $\begin{array}{c}-0.028 \\
(0.013)^{* *}\end{array}$ & $\begin{array}{l}-0.027 \\
(0.017)\end{array}$ & $\begin{array}{c}-0.029 \\
(0.017)^{*}\end{array}$ & $\begin{array}{c}-0.012 \\
(0.062)\end{array}$ & $\begin{array}{c}-0.028 \\
(0.013)^{* *}\end{array}$ & $\begin{array}{c}0.007 \\
(0.112)\end{array}$ & $\begin{array}{c}-0.030 \\
(0.015)^{* *}\end{array}$ & $\begin{array}{l}-0.040 \\
(0.040)\end{array}$ \\
\hline $\mathrm{CBI}$ & & & $\begin{array}{c}1.073 \\
(1.510)\end{array}$ & $\begin{array}{c}2.627 \\
(3.898)\end{array}$ & & $\begin{array}{c}0.910 \\
(5.471)\end{array}$ & $\begin{array}{c}1.268 \\
(1.344)\end{array}$ & $\begin{array}{c}1.674 \\
(1.323)\end{array}$ \\
\hline $\begin{array}{c}\text { CBI x } \\
\text { Openness }\end{array}$ & & & & $\begin{array}{l}-0.038 \\
(0.133)\end{array}$ & & $\begin{array}{l}-0.049 \\
(0.195)\end{array}$ & & \\
\hline $\begin{array}{c}\text { Openness } x \\
\text { Exchange Rate }\end{array}$ & & & & & $\begin{array}{l}0.0001 \\
(0.016)\end{array}$ & $\begin{array}{c}0.011 \\
(0.030)\end{array}$ & & \\
\hline$\Delta$ Inflation & $\begin{array}{c}0.011 \\
(0.138)\end{array}$ & $\begin{array}{l}-0.164 \\
(0.140)\end{array}$ & $\begin{array}{c}0.006 \\
(0.146)\end{array}$ & $\begin{array}{c}0.004 \\
(0.143)\end{array}$ & $\begin{array}{c}0.010 \\
(0.139)\end{array}$ & $\begin{array}{l}-0.098 \\
(0.286)\end{array}$ & $\begin{array}{l}-0.013 \\
(0.141)\end{array}$ & $\begin{array}{l}-0.029 \\
(0.144)\end{array}$ \\
\hline Length & $\begin{array}{c}0.380 \\
(0.170)^{* *}\end{array}$ & $\begin{array}{c}0.407 \\
(0.187)^{* *}\end{array}$ & $\begin{array}{c}0.397 \\
(0.216)^{*}\end{array}$ & $\begin{array}{c}0.396 \\
(0.178)^{* *}\end{array}$ & $\begin{array}{c}0.381 \\
(0.169)^{* *}\end{array}$ & $\begin{array}{c}0.656 \\
(0.308)^{* *}\end{array}$ & $\begin{array}{c}0.398 \\
(0.183)^{* *}\end{array}$ & $\begin{array}{c}0.396 \\
(0.181)^{* *}\end{array}$ \\
\hline $\begin{array}{l}\text { Inflation } \\
\text { Duration }\end{array}$ & $\begin{array}{l}-0.041 \\
(0.072)\end{array}$ & $\begin{array}{c}0.008 \\
(0.082) \\
-0.095 \\
(0.293)\end{array}$ & $\begin{array}{l}-0.020 \\
(0.090)\end{array}$ & $\begin{array}{l}-0.014 \\
(0.078)\end{array}$ & $\begin{array}{l}-0.041 \\
(0.077)\end{array}$ & $\begin{array}{c}0.005 \\
(0.171)\end{array}$ & $\begin{array}{l}-0.011 \\
(0.073)\end{array}$ & $\begin{array}{c}0.006 \\
(0.077)\end{array}$ \\
\hline $\begin{array}{l}\text { Inputs } \\
\text { Union Density }\end{array}$ & & & $\begin{array}{c}0.003 \\
(0.015)\end{array}$ & & & $\begin{array}{c}5.390 \\
(9.510)\end{array}$ & & \\
\hline $\begin{array}{l}\text { Pass-Through } \\
\text { Pass-Through } \\
\text { x Openness }\end{array}$ & & & & & & & $\begin{array}{l}-0.183 \\
(0.639)\end{array}$ & $\begin{array}{c}-0.355 \\
(1.725) \\
0.014 \\
(0.053)\end{array}$ \\
\hline $\begin{array}{c}\text { Adjusted-R } \\
\mathrm{N} \\
\# \text { of Countries }\end{array}$ & $\begin{array}{c}0.181 \\
69 \\
20 \\
\end{array}$ & $\begin{array}{c}0.071 \\
55 \\
16 \\
\end{array}$ & $\begin{array}{c}0.155 \\
65 \\
20 \\
\end{array}$ & $\begin{array}{c}0.172 \\
69 \\
20 \\
\end{array}$ & $\begin{array}{c}0.168 \\
69 \\
20 \\
\end{array}$ & $\begin{array}{c}0.050 \\
47 \\
19 \\
\end{array}$ & $\begin{array}{c}0.169 \\
69 \\
20 \\
\end{array}$ & $\begin{array}{c}0.157 \\
69 \\
20 \\
\end{array}$ \\
\hline
\end{tabular}

$* * *, * *$, and $*$ denote 1,5 , and $10 \%$ levels of significance respectively

Open Economies Review, Vol. 26, No. 1 (February 2015): pg. 39-60. DOI. This article is C Springer and permission has been granted for this version to appear in e-Publications@Marquette. Springer does not grant permission for this article to be further copied/distributed or hosted elsewhere without the express permission from Springer. 
NOT THE PUBLISHED VERSION; this is the author's final, peer-reviewed manuscript. The published version may be accessed by following the link in the citation at the bottom of the page.

\section{About the Authors}

Joseph P. Daniels $\quad$ : Professor of Economics, Department of Economics Marquette University, P.O. Box 1881, Milwaukee, WI 53201

Phone: 414-288-3368; Fax: 414-288-5757

E-mail: Joseph.Daniels@marquette.edu

Sandeep Mazumder : Assistant Professor of Economics, Department of Economics Wake Forest University, Box 7505, Winston-Salem, NC 27109

Phone: 336-758-4519

E-mail:mazumds@wfu.edu

David D. VanHoose

: Professor of Economics and Herman Lay Professor of Private, Enterprise Hankamer School of Business, Baylor University, One Bear Place \#98003, Waco, TX 76798

Phone: 254-710-6206; Fax: 254-710-6142

E-mail: David_VanHoose@baylor.edu

Open Economies Review, Vol. 26, No. 1 (February 2015): pg. 39-60. DOI. This article is (c) Springer and permission has been granted for this version to appear in e-Publications@Marquette. Springer does not grant permission for this article to be further copied/distributed or hosted elsewhere without the express permission from Springer. 